\title{
GANTRY TÍPUSÚ HOBBY CNC MARÓGÉP TERVEZÉSE ÉS ÉPÍTÉSE
}

\section{GANTRY TYPE HOBBY CNC MILLING MACHINE DESIGN AND CONSTRUCTION}

\author{
Péter Álmos Lehel ${ }^{1}$, Faludi Botond ${ }^{2}$, Tolvaly-Roșca Ferenc ${ }^{3}$ \\ ${ }^{I}$ Sapientia EMTE, Müszaki és Humán Tudományok Kar, Románia, 540485 \\ Marosvásárhely (Koronka), Segesvári út 1.C; Telefon / Fax: +40-265-206210/+40- \\ 265-206211,peteralmos2@yahoo.com \\ 2 Sapientia EMTE, Müszaki és Humán Tudományok Kar, Románia, 540485 \\ Marosvásárhely (Koronka), Segesvári út 1.C; Telefon / Fax: +40-265-206210/+40- \\ 265-206211,faludi_botond@indamail.hu \\ ${ }^{33}$ Sapientia EMTE, Müszaki és Humán Tudományok Kar, Gépészmérnöki Tanszék, \\ Románia, 540485 Marosvásárhely (Koronka), Segesvári út 1.C; Telefon / Fax: +40- \\ 265-206210/+40-265-206211,tferi@ms.sapientia.ro
}

\begin{abstract}
Nowadays $\mathrm{CNC}$ machines are widely used in industry environment. Beside the professional CNC machines, the number of the CNC hobby machines made for personal needs and use, has also increased. The present times technologies allows to us, students in second year at mechatronics, to design and build a hobby milling machine, adequate to our personal needs. This machine can also become a base working machine in our personal workshop. Some base idea and realization are presented, together with a first application of the built machine.
\end{abstract}

Keywords: CNC, hobby milling machine, Gantry type

\section{Összefoglalás}

Napjainkban robbanásszerủen elterjedt a CNC szerszámgépek használata az iparban. Az iparban való széleskörüen használt ipari CNC szerszámgépek mellet, kezd nőni a saját célra készített és felhasznált hobby CNC szerszámgépek száma is. A mai technológia lehetővé teszi számunkra, másodéves mechatronikás hallgatók számára azt, hogy megtervezzünk és felépítsünk egy saját készítésü, hobby célt szolgáló CNC marógépet, amit saját igényeinkhez szabhatunk, és ami akár otthoni mühelyünk legfontosabb eszközévé is válhat. Bemutatásra kerül néhány olyan ötletet és megvalósítás, amely segítségével sikerült megépíteni egy ilyen gépet és az első gyakorlati alkalmazása is.

Kulcsszavak: CNC, hobby marógép, Gantry típus

\section{Célkitűzések}

Célkitüzésünk egy olyan CNC marógép készítése, amelyet mind anyagilag, mind tudásunk szintjén meg tudunk valósítani. Elsősorban az altalunk tervezett $\mathrm{CNC}$ marógépet nyomtatott áramkörök készítésére és müanyagok megmunkálásra szeretnénk felhasználni. Itt segítségünkre volt az Interneten megtalálható, hobby $\mathrm{CNC}$ gépekkel foglalkozó fórumon [1] és egy 
gyakorlatilag megvalósított CNC gép képes beszámolója [2].

A megmunkálandó alkatrészek méreteit és anyagát figyelembe véve egy körülbelül 1000x1000 mm marófej-mozgást tüztünk ki célul, így az alábbi paramétereket állapítottuk meg:

- Legkevesebb 1000 X 1000 mm hosszú vezetékek;

- 3Nm-es léptető motorok a golyós orsók meghajtására;

- 48V, 300W teljesítményü, 12.000 fordulat/perc fordulatszámú maró motor.

A szerszámgép mechanikai tervét testmodellként Autodesk Inventorban készítettük el (1. ábra).

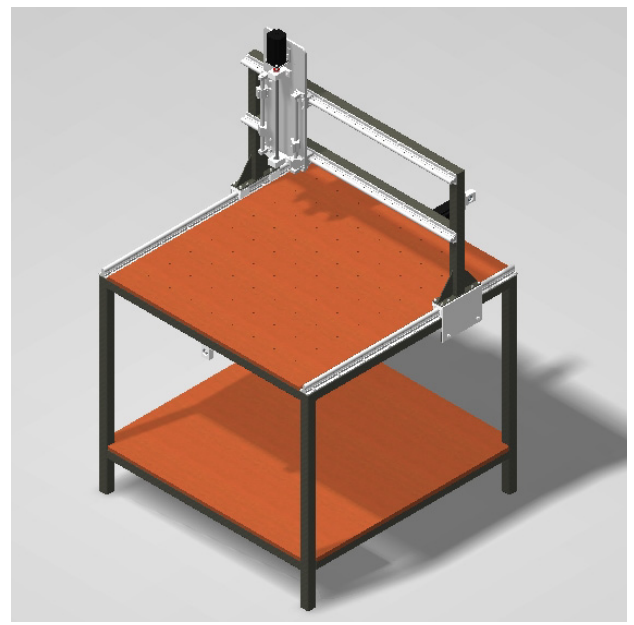

1. ábra. A hobby CNC marógép testmodellje

A három fő mozgást golyós vezetékek segítségével, a tengelyek mozgatását pedig golyós orsó és golyósanyával valósítanánk meg, ezek már elérhető áron megvásárolhatók. A gép szerkezetét acél zárt profilból szeretnénk megépíteni. A leptető motorok vezérlését mikrokontroller és a Mach 3 mozgásvezérlő szoftver segítségével akarjuk megvalósítani.

\section{A szerszámgép tervezése és gyakorlati megvalósítása}

$\mathrm{Az}$ általunk tervezett CNC marógép egy kisebb modellje a gyárakban használt CNC szerszámgépeknek. Természetesen a felhasznált alkatrészek nem ipari árakon és nem ipari pontossággal rendelkező alkatrészek. A 3 tengelyes marógép, három lineáris mozgást képes végezni $1000 X 1000 \mathrm{~mm}$ felületen az OX és OY tengelyek mentén, az $\mathrm{OZ}$ tengely mentén pedig $200 \mathrm{~mm}$-t. Amint az 1. ábrán is látható a tervezett $\mathrm{CNC}$ marógép álló asztalú, Gantry típusú. A 3 tengely menti mozgásokat a marófej végzi.

A szerkezeti vázat 40 × $40 \times 3 \mathrm{~mm}$ acél zárt profilokból készítettük. A végső, megmunkálási pontosság minél magasabb szinten való tartása érdekében, az acélváz elemeinek méretre való szabása és összehegesztése nagy pontosságot igényelt (2. ábra).

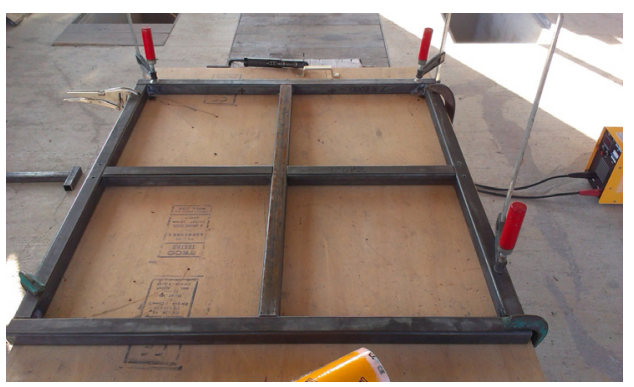

2. ábra. $A$ vázszerkezet hegesztése

A szán mozgatását SFU 1204 típusú golyós orsó és golyósanya segítségével valósítottuk meg. A golyós orsó forgatását $3 \mathrm{Nm}$ nyomatékkal mozgató, Nema 23-as típusú leptető motorokkal valósítottuk meg. Az OX és OY tengely menten való csuszást SBR 16 lineáris vezetékkel és SBR 16 UU csuszkával valósítottunk meg. Az OZ irányú mozgást pedig WCS 12 rúd es SCS 12 csuszkával biztosítottuk. 
A vezetékek szerelése igen pontos beállításokat igényelt, ez a szakasz a $\mathbf{3}$. ábrán látható.

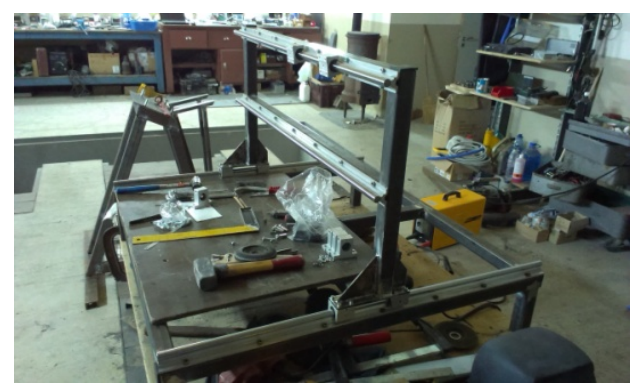

3. ábra. A vezetékek szerelése és beállitása

A forgácsolási sebességet és a hozzá szükséges fordulatszámot egy 48V-os, 12000 fordulat/perc-es $300 \mathrm{~W}$-os DC motor biztosítja. A motor ER11 típusú szerszámbefogó tokmánnyal rendelkezik.

Az motorok vezérlését egy BD25 típusú mikrokontroller, illetve DM542A típusú driver biztosítja. A vágópályák és a $\mathrm{G}$ kódok generálására a SheetCam programot és a Mach3Mill szerszámgép-vezérlő szoftvert használjuk.

Az összeszerelt és beüzemelt gép a 4. ábrán látható.

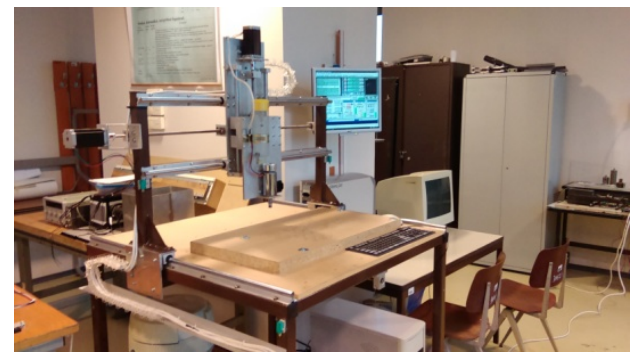

4. ábra. A beüzemelt, gyakorlati alkalmazásra kész hobby CNC marógép

\section{Gyakorlati alkalmazás}

A tervezett marógép megmunkálásra való alkalmazása, jelenlegi műszaki felkészültségünk alapján, 3 szoftver használatát teszi szükségesé. A megmunkálni kívánt darabot Autodesk
Inventor programban tervezzük, majd DXF formátumban SheetCam programban importáljuk. A SheetCam program processzor részével generálhatók a szerszámpályák, majd Mach3Mill posztprocesszort használva kigeneráljuk a vezérléshez szükséges $G$ kódokat, ezeket majd a Mach3Mill vezérlöprogramba olvassuk be.

$\mathrm{Az}$ első teljes megmunkálásunk Inventor modellje a 5. ábrán látható. Ez csupán egy egyszerü kéttengelyes megmunkálás, de kezdeti eredménynek egyik legnagyobb sikerélményünk lett.

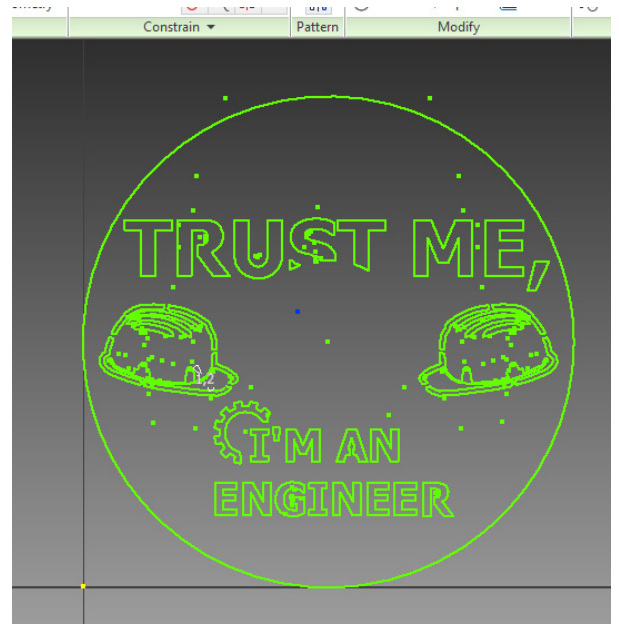

5. ábra. A darab Inventor modellje

A modellt DXF formátumban a SheetCam programba importáltuk (6. ábra).

A megmunkált darab egy hagyományos bakelit hanglemez volt. Az anyagnak megfelelően az előtolást $1500 \mathrm{~mm} /$ perc-re, a teljes $2 \mathrm{~mm}$-es marási mélységet, a beállított $1 \mathrm{~mm}$-es fogásmélységgel két lépésben értük el, a maró fordulatszámát pedig 6000 fordulat/perc-re állítottuk be. Majd az generált szerszámpályákra a SheetCam-ban, a G kódokból álló megmunkáló programot is előállítottuk, Mach3Mill vezérlésére. 


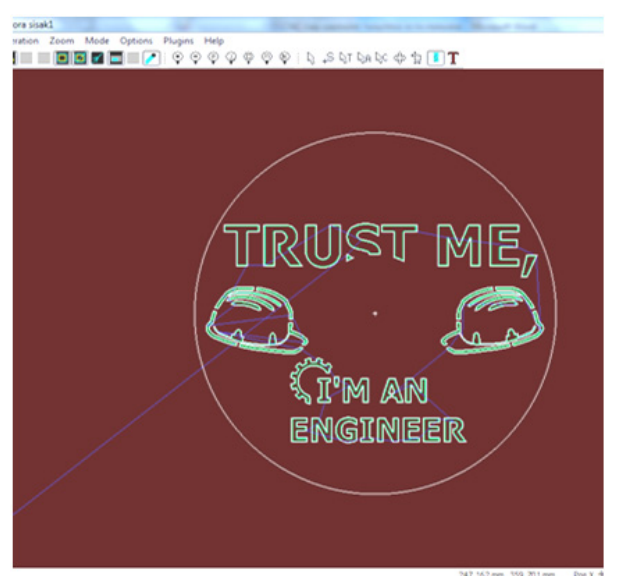

6. ábra. A SheetCam-ba generált szerszámpályák

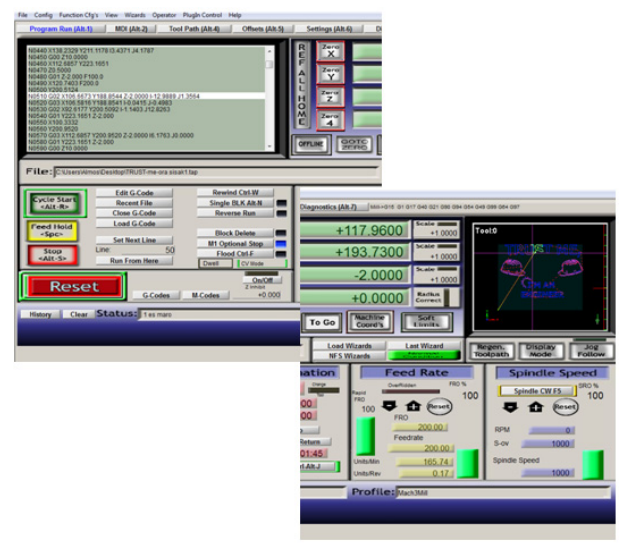

7. ábra. Mach3Mill és a megmunkálási program

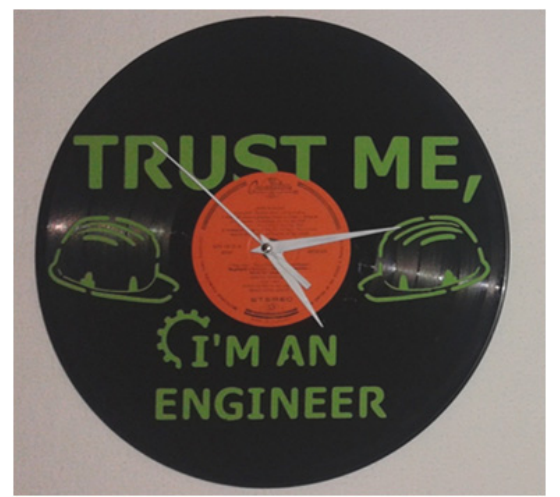

8. ábra. Órának szerelt kész darab
Ezt betöltöttük, amint az 7. ábrán látható, a Mach3Mill vezérlőprogramba.

A megmunkálás 8 perc és 24 másodperc alatt járt le. Ennek az eredménye a 8. ábrán látható (erre már egy mutatós óraszerkezetet is azonnal felszereltünk).

\section{Következtetések}

$\mathrm{Az}$ általunk tervezett és megvalósított Gantry típusú CNC marógép igazi kihívást jelentett másodéves hallgatóknak. Természetesen, hogy a szerelés során is akadtak gondjaink, amelyeket a jelen dolgozaton belül nincs módunkban részletezni. Apróbb gondjaink voltak úgy a beüzemelésnél, mint a szoftverek beállításánál és használatnál. Amikor szükségét éreztük a segítséget kértünk oktatóinktól és tanárainktól.

$\mathrm{Az}$ elért eredmény egyik legfontosabb része a tudás, amelyre szert tettünk a tervezés, kivitelezés és megmunkálások során.

Levonhatjuk a következtetést, hogy nem túl nagy anyagi befektetéssel, nagy elhatározással és kis segítséggel lehetséges hobby CNC szerszámgép előállítása.

Ugyanakkor megállapíthatjuk, hogy nem túl igényes megmunkálásokra, gravírozásra, és ha a megfelelö anyagokat használjuk előgyártmánynak, nem terhelve túl a motorokat és szánokat, szerszámgépünk teljességgel megfelel egy hobby szerszámgép céljainak.

\section{Szakirodalmi hivatkozások}

[1] http://hobbycncart.com/publ/cikkek/elektroni kai_temaju/leptetomotorok_es_vezerlok/4-1$0-1 \overline{8}$

[2] http://www.sasovits.hu/cnc/index.html 